\title{
POPULATION BIOLOGY AND YIELD PER RECRUIT OF BLUE SWIMMING CRAB Portunus pelagicus IN BARDAWILL LAGOON, NORTH SINAI, EGYPT
}

\author{
Mohamed Salem Ahmed
}

Faculty of Aquaculture and Marine Fisheries, Arish University

Crabs are considered non-native crustacean species in Bardawill lagoon which require more studies. Length frequency analysis were used to estimate size distribution, Growth, maturity, mortality and yield per recruit of Blue swimming crab, Portunus pelagicus in Bardawill lagoon during the fishing season 2016. Samples were obtained from trammel fishing vessels. Carapace width of 1068 samples ranged from 4.7 to $13.4 \mathrm{~cm}$ and total weight from 10.4 to $198.3 \mathrm{~g}$. Size distribution showed the major portion of the catch ranged of 8 to $10.9 \mathrm{~cm}$ carapace width. FiSAT II computer program was used to estimate the growth parameters as $\mathrm{L} \infty=14.3 \mathrm{~cm}$ and $\mathrm{K}=1.1 \mathrm{yr}^{-1}$. The growth performance index ( $\left.\varnothing^{\prime}\right)$ equal 2.358. Recruitment was extent from June to October. Sex ratio between male and female were 1.09: 1 . The size at first maturity $\left(\mathrm{CWm}_{50}\right)$ was estimated at $9.1 \mathrm{~cm}$. Total, natural and fishing mortality rates were $4.25 \mathrm{yr}^{-1}, 1.6 \mathrm{yr}^{-1}$ and $2.65 \mathrm{yr}^{-1}$ respectively. Size at first capture $\left(\mathrm{CWc}_{50}\right)$ was $8.6 \mathrm{~cm}$. The current exploitation $\left(\mathrm{E}_{\text {curr }}=0.62\right)$ lower than the economic exploitation rate $\left(\mathrm{E}_{-} 10 \%=0.76\right)$ and maximum exploitation rate $\left(\mathrm{E}_{\text {-max }}=0.86\right)$. Stock of Blue crab in Bardawill lagoon should be controlled by increased the fishing effort to MEY and MSY level, as this species may be become dangerous on native species in region.

Keywords: Portunus pelagicus, Bardawill lagoon, growth parameters and yield per recruit 